\title{
Resilience Of Efficacy Perawat Berbasis Tingkat Stres dan Kepuasan Kerja
}

\author{
Nian Afrian Nuari \\ Program Studi Keperawatan, STIKES Karya Husada Kediri \\ Email: nian.afrian@yahoo.co.id
}

\begin{abstract}
Resilience Of Efficacy of Nurse Based On Level of Stress and Work Satisfaction. A nurse must be able to balance the various stressors obtained in the work environment because they have to provide professional services to patients. This requires personal factors inherent in the nurse so as to adapt to stressful conditions. Internal factors include the ability to withstand the problem (resilience of efficacy). The purpose of this study was to determine the correlation resilience of efficacy with the level of stress and job satisfaction nurses in RS X. The research method was a correlational study with purposive sampling and sample size of 30 respondents. The instruments were used questionnaires then analyzed with Spearman rho test. Based on the result, the majority $(56,7 \%)$ respondents have high category resilience of efficacy, the majority $(80 \%)$ have light work stress and most of them $(93,3 \%)$ have high job satisfaction. The results of research obtained, resilience of efficacy with nurse work stress level $(p=0,039$, cc=-0,393), resilience of efficacy with nurse job satisfaction ( $p$-value $=0,007$, and $c c=0,469$ ). This means there was a correlation between the resilience of efficacy with work stress and nurse job satisfaction. It is expected that nurses need to do a good coping strategy for overcoming the problems found. The higher the resilience of efficacy the lower the stress level will be and it will increase the nurse's comfort in working so that it can improve job satisfaction.
\end{abstract}

Keywords: Resilience, Efficacy, Stress, Satisfaction, Nurse

\begin{abstract}
Abstrak: Resilience Of Efficacy Perawat Berbasis Tingkat Stres Dan Kepuasan Kerja. Seorang perawat harus mampu menyeimbangkan berbagai stressor yang didapatkan di lingkungan kerja karena harus memberikan pelayanan professional kepada pasien. Hal ini diperlukan faktor personal yang melekat dalam diri perawat sehingga mampu beradaptasi dengan kondisi stres. Faktor internal yang dimiliki meliputi kemampuan dalam bertahan menghadapi masalah (resilience of efficacy). Tujuan penelitian ini untuk mengetahui hubungan resilience of efficacy dengan tingkat stres dan kepuasan kerja perawat di RS X. Metode penelitian yang digunakan adalah korelasional dengan teknik purposive sampling dan jumlah sampel 30 responden. Alat ukur yang digunakan kuesioner dan dianalisis dengan uji statistik spearman rho.Berdasarkan hasil penelitian didapatkan sebagian besar $(56,7 \%)$ responden memiliki resilience of efficacy kategori tinggi, sebagian besar $(80 \%)$ responden memiliki stres kerja ringan dan hampir sebagian besar $(93,3 \%)$ memiliki kepuasan kerja yang tinggi. Hasil analisis dengan uji spearman rho didapatkan resilience of efficacy dengan tingkat stres kerja perawat $(p=0,039$, cc $=-0,393)$, resilience of efficacy dengan kepuasan kerja perawat ( $p$-value $=0,007$, dan $c c=0,469)$. Hal ini berarti ada hubungan antara resilience of efficacy dengan stres kerja dan kepuasan kerja perawat. Diharapkan perawat perlu melakukan strategi koping yang baik dalam mengatasi permasalahan yang ditemukan. Semakin tinggi resilience of efficacy maka tingkat stres yang dimilikinya akan lebih rendah dan hal itu akan mampu meningkatkan kenyamanan perawat dalam bekerja sehingga dapat meningkatkan kepuasan kerja.
\end{abstract}

Kata kunci: Resilience, Efficacy, Stres, Kepuasan, Perawat

Seorang perawat harus mampu menyeimbangkan antara berbagai stressor yang didapatkan di lingkungan kerja dan pelayanan yang harus diberikan oleh seorang perawat professional sehingga diperlukannya faktor internal untuk mengatasi hal tersebut. Ketika ada sebuah stressor dalam lingkungan kerja terjadi seseorang perlu kemampuan untuk mengatasi hal tersebut secara efektif. Permasalahan stres kerja merupakan permasalahan yang perlu mendapatkan perhatian karena masalah tersebut akan berdampak pada produktifitas dan juga kinerja dari karyawan. Stres kerja merupakan masalah utama bagi karyawan dan organisasi, serta dapat menyebabkan kelelahan, sakit, perputaran tenaga kerja, dan ketidakhadiran. Stres kerja pun terjadi di negara-negara Asia yang sudah masuk kategori negara maju, seperti 
di Singapura kekurangan staf, tuntutan kerja yang tinggi, dan konflik di tempat kerja menjadi penyebab utama stres kerja (Lim, Msocsci, Bogossian, \& Ahern, 2010 dalam Yana 2015). Stres kerja dapat berupa perasaan atau emosi yang tertekan, tidak senang terhadap suatu keadaan pekerjaan atau keadaan di dalam lingkungan kerja yang dihadapi oleh mental, fisik, emosional dan spiritual yang pada suatu saat dapat mempengaruhi kesehatan fisik (Kriswandaru, 2010).

Salah satu faktor internal yang dapat mempengaruhi kemampuan perawat dalam mengatasi kesulitan atau stressor yang ada adalah ketahanan mental atau juga disebut resilience of efficacy. Secara umum, resilience of efficacy bermakna kemampuan seseorang untuk bangkit dari keterpurukan yang terjadi dalam perkembangannya. Resilience of efficacy dapat dianggap sebagai proses adaptasi terhadap kesulitan dan stres. Menurut Bandura (2002), Konsep self efikasi adalah kemampuan/ potensi seseorang untuk melaksanakan tugas dalam kondisi atau situasi tertentu. Dalam hal ini jika seorang perawat mampu menghadapi tekanan di lingkungan kerja serta mampu memberikan pelayan yang optimal dapat dikatakan perawat tersebut memiliki resilience of efficacy dan self efikasi yang tinggi. Sebaliknya jika seorang perawat tidak mampu menghadapi hal tersebut dia akan mencoba menghindar dari masalah, menganggapnya sebagai kesulitan yang tidak ada solusinya.

Perawat yang tangguh cenderung akan pulih dari keadaan yang buruk atau trauma dan menggambarkan karakteristik yang membantu mereka mengatasi tantangan hidup di lingkungan. Proses dinamis ini yang menunjukkan kemampuan perawat dalam menanggapi keadaan hidup, profil kepribadian individu, dan merupakan penanda kehidupan yang baik serta menunjukkan kepribadian yang matang secara psikologis (Eley, Diann S et al, 2013). Faktor interpersonal perawat sangat penting sebagai mekanisme koping dari stres kerja. Seperti halnya Resilience of efficacy perawat dapat menopang perawat dalam menghadapi tantangan dan kondisi pekerjaan yang sulit. Secara umum, resilience of efficacy sangat penting dalam membangun kemampuan individu untuk merespon stressor di tempat kerja serta kemampuan individu mengatasi kelelahan bekerja, kecemasan, hingga depresi (Rees dkk, 2015).

Perawat yang mampu melakukan koping yang baik terhadap stres akan mampu menciptakan suasana kehidupan kerja yang baik sehingga mampu meningkatkan kinerja dan kepuasan kerja perawat. Peningkatan kinerja dan kepuasan kerja akan meningkatkan daya saing terhadap kompetitif perumahsakitan saat ini (Mangkunegara, 2004). Berdasarkan penelitian Nian Afrian (2016), ketidaksukaan individu terhadap pekerjaan berdampak pada motivasi dan kepuasan kerja yang dimiliki oleh pasien tersebut. Perawat yang tidak mampu mengatasi masalahnya cenderung akan kurang mempunyai motivasi dalam bekerja sehingga berimbas pada kinerja yang kurang baik.

Berdasarkan latar belakang di atas, peneliti tertarik melakukan penelitian tentang hubungan resilience of efficacy dengan tingkat stres dan kepuasan kerja perawat. Tujuan penelitian ini adalah: 1) menganalisis hubungan resilience of efficacy dengan tingkat stres perawat di RS Amelia, 2) menganalisis hubungan resilience of efficacy dengan kepuasan kerja perawat di RS Amelia.

\section{METODE}

Jenis penelitian kuantitatif dengan pendekatan cross sectional. Populasi yang diteliti adalah semua perawat dirumah sakit Amelia Pare dan sampel diambil dengan teknik purposive sampling dengan 30 responden. Variabel penelitian adalah resilience of efficacy, tingkat stres perawat, kepuasan kerja perawat. Data dikumpulkan dengan menggunakan kuesioner. Pengumpulan data dilakukan selama 1 bulan pada bulan Maret 2017. Analisis data dilakukan dengan uji statistik Spermean Rho dengan signifikansi 0,05 (Dahlan, S, 2011).

\section{HASIL}

\section{Distribusi Frekuensi Responden Berdasarkan Usia}

Tabel 1. Distribusi
\begin{tabular}{ccc} 
Berdasarkan Usia & Frekuensi & Responden \\
\hline Usia & Frekuensi & $\%$ \\
\hline $20-40$ tahun & 23 & 76,7 \\
\hline $41-60$ tahun & 7 & 23,3 \\
\hline
\end{tabular}

Berdasarkan data di atas didapatkan bahwa sebagian besar $(76,7 \%)$ yaitu 23 responden berusia $20-40$ tahun dan 7 orang $(23,3 \%)$ berusia 41-60 tahun. 
2. Distribusi Frekuensi Responden Berdasarkan Lama kerja

Tabel 2. Distribusi Frekuensi Responden Berdasarkan Lama Kerja

\begin{tabular}{crr}
\hline Lama Kerja & \multicolumn{1}{c}{ Frek } & \multicolumn{1}{c}{$\%$} \\
\hline$<1$ tahun & 1 & 3,33 \\
\hline $1-4$ tahun & 6 & 20 \\
\hline$>4$ tahun & 23 & 76,7 \\
\hline
\end{tabular}

Berdasarkan data di atas menunjukkan bahwa sebagian besar $(76,7 \%)$ lama kerja $>4$ tahun.

\section{Distribusi Frekuensi Responden} Berdasarkan Jenis Kelamin

Tabel 3. Distribusi Frekuensi Responden Berdasarkan Jenis Kelamin

\begin{tabular}{lrc}
\hline \multicolumn{1}{c}{ Jenis kelamin } & Frek & \% \\
\hline Laki-laki & 13 & 43,3 \\
\hline Perempuan & 17 & 56,7 \\
\hline
\end{tabular}

Berdasarkan tabel di atas dapat diketahui bahwa laki-laki dan perempuan menunjukkan sebagian besar $(56,7 \%)$ responden berjenis kelamin perempuan.

\section{Distribusi Frekuensi Responden} Berdasarkan Status Pernikahan

Tabel 4. Distribusi Frekuensi Responden Berdasarkan Status Pernikahan

\begin{tabular}{lrc}
\hline Status Pernikahan & Frek & \% \\
\hline Menikah & 27 & 90 \\
\hline Belum menikah & 3 & 10 \\
\hline
\end{tabular}

Berdasarkan data di atas menunjukkan bahwa hampir seluruhnya (90\%) memiliki status sudah menikah.

\section{Distribusi Frekuensi Responden} Berdasarkan Pendidikan

Tabel 5. Distribusi Frekuensi Responden Berdasarkan Pendidikan

\begin{tabular}{lrr}
\hline Pendidikan & Frek & \multicolumn{1}{c}{$\%$} \\
\hline D3 Kep & 28 & 93,7 \\
\hline S1 Kep & 2 & 6,7 \\
\hline
\end{tabular}

Berdasarkan data di atas menunjukkan bahwa pendidikan terakhir perawat hampir seluruhnya $(93,7 \%)$ jenjang pendidikan D3 Keperawatan.

\section{Distribusi Frekuensi Responden Berdasarkan Quality Work Of Life}

Tabel 6. Distribusi Frekuensi Responden Berdasarkan Resilience Of Efficacy

\begin{tabular}{lrr}
\hline Resilience Of Efficacy & \multicolumn{1}{c}{ Frek } & \multicolumn{1}{c}{$\%$} \\
\hline Rendah & 4 & 13,3 \\
\hline Sedang & 9 & 30 \\
\hline Tinggi & 17 & 56,7 \\
\hline
\end{tabular}

Berdasarkan tabel di atas, resilience of efficacy pada perawat RS X sebagian besar $(56,7 \%)$ mempunyai Resilience of efficacy tinggi.

Tabel 7. Distribusi Komponen Resilience Of Efficacy Pada Perawat

Komponen Resilience Of Mean Median

\begin{tabular}{lll}
\multicolumn{1}{c}{ Efficacy } & & \\
\hline Neuroticism & 15.9268 & 16.0000 \\
\hline Mindfulness & 15.8571 & 15.5000 \\
\hline Self-efficacy & 15.7143 & 17.0000 \\
\hline Coping & 16.4286 & 17.0000
\end{tabular}

Berdasarkan tabel di atas diketahui bahwa komponen resilience of efficacy yang mempunyai Mean tertinggi adalah komponen koping.

7. Distribusi Frekuensi Responden Berdasarkan Tingkat Stres Kerja

Tabel 8. Distribusi Frekuensi Responden Berdasarkan Tingkat Stres Kerja

\begin{tabular}{lrr}
\hline Kepuasan Kerja & \multicolumn{1}{c}{ n } & \multicolumn{1}{c}{$\%$} \\
\hline Tidak Stres & 0 & 0,0 \\
\hline Stres Kerja Ringan & 24 & 80,0 \\
\hline Stres Kerja Sedang & 6 & 20 \\
\hline Stres Kerja Berat & 0 & 0,0 \\
\hline
\end{tabular}

Berdasarkan tabel di atas diketahui bahwa sebagian besar (80\%) responden mempunyai tingkat stres kerja dalam kategori stres ringan.

Tabel 9. Distribusi Komponen Stres Kerja Pada Perawat

\begin{tabular}{lrr}
\hline \multicolumn{1}{c}{ Komponen Stres } & \multicolumn{1}{c}{ Mean } & \multicolumn{1}{c}{ Median } \\
\hline Fisiologi & 19.1071 & 19.0000 \\
\hline Psikologis & 9.3571 & 9.0000 \\
\hline Perilaku & 14.2857 & 14.0000 \\
\hline
\end{tabular}

Berdasarkan tabel di atas diketahui bahwa faktor fisiologis mempunyai mean tertinggi dari pada faktor psikologis dan perilaku. 


\section{Distribusi Frekuensi Responden Berdasarkan Kepuasan Kerja}

Tabel 10. Distribusi Frekuensi Responden Berdasarkan Kepuasan Kerja

\begin{tabular}{lrr}
\hline Kepuasan Kerja & Frek & \multicolumn{1}{c}{$\%$} \\
\hline Tinggi & 28 & 93,3 \\
\hline Sedang & 2 & 6,7 \\
\hline Rendah & 0 & 0 \\
\hline
\end{tabular}

Berdasarkan tabel di atas kepuasan kerja yang dimiliki perawat RS Amelia Pare hampir seluruhnya $(93 \%)$ memiliki kepuasan kerja yang tinggi.

\section{Tabel Hasil Uji Statistik}

Tabel 11. Hasil Uji Statistik

\begin{tabular}{llll}
\hline $\begin{array}{c}\text { Hubungan } \\
\text { Antar Variabel }\end{array}$ & n & p-value & cc \\
\hline $\begin{array}{l}\text { resilience of } \\
\text { efficacy dengan }\end{array}$ & 30 & 0,039 & $-0,393$ \\
tingkat stres & & & \\
kerja perawat & & & \\
\hline $\begin{array}{l}\text { resilience of } \\
\text { efficacy dengan }\end{array}$ & & 0,007 & 0,469 \\
kepuasan kerja \\
perawat
\end{tabular}

Berdasarkan tabel diatas terdapat hubungan antara resilience of efficacy dengan tingkat stres kerja perawat dan juga terdapat hubungan antara resilience of efficacy dengan kepuasan kerja perawat. Hal ini berarti ada hubungan antara resilience of efficacy dengan tingkat stres kerja dan kepuasan kerja perawat di RS Amelia.

\section{PEMBAHASAN}

\section{Hubungan Resilience Of Efficacy dengan Stres Kerja}

Berdasarkan hasil penelitian tentang resilience of efficacy pada perawat RS Amelia sebagian besar $(56,7 \%)$ yaitu 17 responden resilience of efficacy tinggi dan sebagian besar (80\%) yaitu 24 responden mempunyai tingkat stres kerja dalam kategori stres ringan. Stres di tempat kerja berhubungan dengan masalah psikososial, seperti terlalu tingginya beban kerja, tuntutan waktu, kurangnya evaluasi beban kerja, kurangnya dukungan sosial antara teman sejawat, diskriminasi dapat memicu terjadinya stres kerja.

Resilience of efficacy yang diartikan kemampuan untuk bangkit dari keadaan terpuruk dan merupakan gambaran dari proses dan hasil keberhasilan beradaptasi dengan keadaan yang sulit atau pengalaman hidup yang dapat menyebabkan stres. Kemampuan untuk bertahan dalam keadaan tertekan atau bahkan berhadapan dengan kesengsaraan (adversity) dipengaruhi oleh kerentanan (neuroticism), pemikiran (mindfulness), self-efficacy, dan coping individu yang berbeda-beda.

Kerentanan (neuroticism) pada perawat adalah beban kerja perawat, berdasarkan data seorang perawat menangani 6-7 pasien setiap harinya dengan kasus yang beragam.Hal ini sejalan dengan hasil penelitian Haryanti (2013) dimana sebagian besar memiliki beban kerja yang tinggi.Beban kerja bisa menjadi kerentanan resilience of efficacy individu karena faktor ini bisa memperbesar potensi terjadinya resiko berkembangnya perilaku atau respon maladaptif individu.Selain itu, status pernikahan bisa mejadi kerentanan resilience of efficacy.

Pemikiran (mindfulness) pada perawat dapat diidentifikasi dari pendidikan.Kemampuan berfikir individu dapat memfasilitasi pelepasan penilaian terhadap stressor menjadi metakognitif dimana pikiran tentang stressor dapat dinilai dengan perspektif yang lebih besar dan mengurangi tanggapan yang reaktif. Dengan cara ini individu untuk tetap fokus pada masalah dan memungkinkan menilai suatu masalah dengan seimbang.

Berdasarkan hasil penelitian beberapa hal yang mempengaruhi tingkat intelegensi responden adalah sebanyak $93,7 \%$ responden merupakan lulusan diploma. Namun, mindfulness didukung juga oleh self efficacy yang mencakup usia, jenis kelamin, tingkat intelegensi dan karakteristik keluarga. Hal ini senada dengan penelitian Nuari, NA (2015), bahwa resiliensi seseorang sangat erat berkaitan dengan individual factor, personal skill, social support, peer support. Indikator spiritual, edukasi dan kultur juga berpengaruh signifikan dalam resiliensi. Resiliensi juga dipengaruhi faktor spiritual atau agama karena agama juga merupakan faktor protektif eksternal. Faktor budaya memberikan pengaruh dalam perkembangan resiliensi individu (Nuari,NA, 2015).

Berdasarkan hasil penelitian sebagian besar responden $(76,7 \%)$ berusia 20-40 tahun. Pada usia ini individu masih belajar dalam penyesuaian lingkungan kerja selain itu pada dewasa muda memiliki kecemasan terhadap tuntutan sebagai perawat yang terlalu banyak, kerja yang memiliki beban berat, atau perlunya membuat keputusan yang mempengaruhi hidup 
orang lain dalam melakukan pelayanan kesehatan (Feldman, 2012).

Awal masa dewasa selain merupakan masa penyesuaian terhadap pekerjaan, dewasa muda juga memiliki kemampuan untuk mengembangkan tujuan hidup dan membuat pilihan karir pekerjaan serta sering kali berpusat pada bagian penting dari pembentukan identitas mereka. Hal ini sesuai dengan penelitian Haryuni dkk (2013) yang menunjukkan bahwa usia dewasa muda memiliki kinerja yang baik. Adanya kemampuan penyesuaian dalam pekerjaan membuat dewasa muda mampu beradaptasi dengan baik.Sehingga resiliensi terbentuk dari self efficacy atau dari keyakinan individu terhadap kemampuannya.

Berdasarkan hasil penelitian $56,7 \%$ responden adalah perempuan. Perempuan memiliki lebih banyak hormon prolaktin yang memberikan umpan negatif terhadap otak, sehingga dapat meningkatkan trauma emosional dan stres fisik (Corwin, 2007). Kecenderungan perempuan yang berfokus terhadap emosi dibandingkan laki-laki yang berfokus terhadap kemampuan logikanya menjadikan perempuan mudah mengalami stres terutama stres kerja.Secara umum, perempuan mengevaluasi diri mereka sendiri lebih keras dibanding lakilaki dalam lingkungan kerja (Feldman, 2012). Hal ini sejalan dengan teori dalam Papalia dkk (2009) bahwa perempuan sering memiliki rasa penyesalan terhadap pekerjaannya, namun kebanyakan perempuan juga mampu mengubah hidupnya dan mencapai kesejahteraan.Hal ini menunjukkan perempuan lebih mudah bangkit dari masalah dan mampu mengubahnya menjadi keadaan yang bisa diatasi.

Status pernikahan juga memberi pengaruh terhadap tingkat stres, pada penelitian menunjukkan $90 \%$ responden menikah. Status menikah akan memberikan peran ganda baik pada laki-laki ataupun perempuan. Perempuan umumnya memiliki peran ganda yaitu sebagai pekerja dan ibu rumah tangga, hal ini akan meningkatkan tekanan psikologis terhadap individu.

Pendidikan dan pengalaman bekerja serta pelatihan perawat akan mempengaruhi kemapuan perawat dalam mengambil keputusan, khususnya perawat di UGD yang dituntut mengambil keputusan yang cepat dan tepat. Berdasarkan hasil penelitian sebagian besar responden merupakan lulusan diploma dan sebagian besar perawat memiliki pengalaman kerja selama $>4$ tahun, hal ini sejalan dengan teori kemampuan kognitif akan membuat individu lebih tenang dalam mengambil keputusan, karena respons individu dalam berbagai situasi merupakan pola penguatan (reinforcement) dari pengalaman masa lalu (Feldman, 2012).

Riwayat pekerjaan juga berkontribusi dalam self efficacy dengan $76,7 \%$ memiliki pengalaman kerja $>4$ tahun. Hal ini sesuai dengan penelitian Mariani (2011) tentang faktorfaktor personal sebagai prediktor terhadap resiliensi perawat dengan hasil ada hubungan antara self efficacy dengan resiliensi. Hal ini menunjukkan bahwa self efficacy yang merupakan faktor protektif yang terbentuk karena proses kognitif berupa keputusan, keyakinan tentang sejauh mana individu meyakini kemampuan dirinya dalam melaksanakan tugas atau tindakan tertentu yang diperlukan untuk mencapai hasil yang diinginkan.

Berdasarkan hasil mean tertinggi, coping memiliki kontribusi yang besar terhadap resiliensi perawat. Faktor coping pada perawat dapat terjadi karena hubungan dan jaringan profesional yang positif. Hubungan sebagai teman kerja sangat krusial bagi perawat, teman kerja akan menjadi sebuah support system. Perawat membutuhkan orang lain untuk memberikan bimbingan dan dukungan di lingkungan kerja ketika kita membutuhkan. Selain itu, perawat yang mampu mempertahankan sikap positif, meningkatkan wawasan emosi, serta memiliki keseimbangan hidup dan spiritualitas akan memiliki resiliensi yang tinggi.

Perawat yang mampu menghadapi stres di lingkungan kerja secara optimis akan mengambil langkah langsung untuk mempelajari dan mengatasi stressor, sehingga mereka mampu mengubah stres ke dalam keadaan yang tidak terlalu mengancam. Serta gejala-gejala stres kerja seperti gejala fisiologi, psikologis, serta perilaku tidak berdampak bagi perawat. Perawat yang setiap harinya dihadapkan pada kesulitan di tempat kerja, resiliensi merupakan kunci bagi pemulihan psikologis perawat. Dengan tingkat resiliensi yang tinggi perawat akan mampu mengontrol perasaan atau emosi mereka terhadap keadaan yang dialami. Bahkan jika terdapat keadaan sangat buruk perawat akan bekerja dengan semua kemapuan yang dimiliki dan berbuat yang terbaik dalam setiap situasi di lingkungan kerja.

Dukungan sosial mampu membantu perawat dalam mengatasi stres kerja dan meningkatkan resiliensi. Orang-orang yang menjadi bagian dari jaringan dukungan sosial akan mudah mendapatkan informasi, nasehat 
tentang cara yang tepat dalam mengatasi stres. Dukungan sosial juga akan meningkatkan tingkat resiliensi individu, seperti keikutsertaan individu dalam komunitas yang mendukung akan membangkitkan individu dari keterpurukan.

Berdasarkan analisis dengan uji Spearman Rho didapatkan hasil terdapat hubungan antara resilience of efficacy dengan tingkat stres kerja perawat ( $p$-value $=0,039$ dan $\mathrm{cc}=-0,393)$. Semakin tinggi resilience of efficacy maka semakin ringan tingkat stres kerja perawat. Hubungan stres kerja dengan resilience of efficacy terbentuk karena faktor internal dan eksternal. Faktor internal, yakni merupakan faktor yang ada dalam diri individu, meliputi keterampilan sosial seperti berkomunikasi, kemampuan meyelesaikan masalah, kecenderungan atribusi sosial (locus of control) dalam menilai penyebab masalah, memiliki kontrol atas diri sendiri, dan tujuan hidup. Sedangkan faktor eksternal yakni segala karakteristik lingkungan yang dapat memengaruhi berkembangnya faktor protektif internal, seperti keikutsertaan individu dalam suatu komunitas yang mendukung, memiliki hubungan akrab dengan lingkungan sekitar. Faktor-faktor tersebut merupakan dasar individu dalam mengatasi stres, dan ketika stres dapat diatasi kemampuan untuk bangkit atau resiliensi akan meningkat. Selain itu, yang mempengaruhi hubungan stres kerja dan resiliensi pada penelitian ini adalah tingkat stressor yang dialami responden belum merupakan stressor yang kuat. Stressor yang kuat seperti kejadian bencana akan mempengaruhi secara simultan dan menetap. Ketika keadaan yang buruk tidak terjadi, maka tingkat resiliensi individu belum teruji dengan baik sehingga resiliensi masih dalam kategori tinggi.

Resilience of efficacy perawat yang tinggi merupakan proses dari menghadapi kesulitan dan tekanan di lingkungan kerja serta erat kaitannya dengan faktor personal. Berdasarkan penelitian yang dilakukan Luthans (2006) resiliensi menjadi faktor yang sangat diperlukan untuk dapat mengubah ancaman-ancaman menjadi kesempatan untuk bertumbuh, berkembang, dan meningkatkan kemampuan untuk beradaptasi demi perubahan yang baik. Kemampuan menilai diri, memiliki harapan yang positif akan diri di masa yang akan datang, dan kemampuan menyelesaikan masalah akan meningkatkan kemampuan perawat menghadapi masalah sebesar dalam hal ini adalah stres kerja (Yuniar, et all, 2012).

\section{Hubungan Resilience Of Efficacy dengan Kepuasan Kerja}

Berdasarkan hasil penelitiandidapatkan data hasil penelitian resilience of efficacy dengan kepuasan kerja perawat di RS X ( $p$-value $=0,007$, dan $\mathrm{cc}=0,469)$. Resilience of efficacy yang diartikan kemampuan untuk bangkit dari keadaan terpuruk dan merupakan gambaran dari proses dan hasil keberhasilan beradaptasi dengan keadaan yang sulit atau pengalaman hidup yang dapat menyebabkan stres. Kepuasan kerja menggambarkan kesukaaan atau ketidaksukaan perawat terhadap pekerjaanya (Mathew, 2013). Bila terdapat perawat yang memiliki kepuasan kerja yang rendah diduga perawat memliki rasa ketidaksukaan dalam bekerja. Ketidaksukaan individu terhadap pekerjaan berdampak adanya niat untuk meninggalkan pekerjaan (Mutukrisnhan, 2011).

Seseorang yang mempunyai resiliensi tinggi akan cenderung bisa mengatasi berbagai permasalahan dalam kehidupannya, hal itu mendorong seseorang untuk melakukan pekerjaannya tanpa beban dan tanpa stres. Hal ini memungkinkan individu untuk mencapai kepuasan kerja yang tinggi. Hal ini senada dengan penelitian Nuari, NA (2016), yang menyatakan bahwa perawat yang mempunyai kehidupan kerja yang baik dan nyaman akan berkorelasi dengan pencapaian kepuasan individu terhadap pekerjaannya. Kepuasan kerja tentu sangat bergantung pada kualitas kehidupan kerja yang dimiliki oleh perawat, dengan terpenuhinya kualitas kehidupan kerja seorang perawat maka ia akan termotivasi untuk mencapai apa yang di inginkannya serta membantu rumah sakit dalam mencapai tujuannya (Nuari, NA, 2016).

\section{SIMPULAN}

Berdasarkan penelitian diatas didapatkan kesimpulan bahwa terdapat hubungan yang signifikan antara resilience of efficacy dengan Tingkat Stres Kerja Perawat dan kepuasan kerja perawat di RS X. Perawat yang mempunyai tingkat resilience of efficacy yang tinggi meliputi strategi coping dan self efficacy akan membuat seseorang mampu mengelola stres yang dimilikinya sehingga mampu mempunyai kepuasan kerja yang baik. 


\section{SARAN}

Perawat perlu melakukan strategi koping yang baik dalam mengatasi permasalahan yang ditemukan dalam kehidupannya. Semakin tinggi resilience of efficacy maka tingkat stres yang dimilikinya akan lebih rendah dan hal itu akan

\section{DAFTAR PUSTAKA}

Bandura, Albert. 2002. Self Efficacy: The Exercise of Control. New York: W. H.. Freeman \& Company.

Corwin, E. J. 2007. Buku Saku Patofisiologi (Edisi 3). Jakarta: Penerbit Buku Kedokteran. EGC.

Dahlan, S. 2011. Statistik Untuk Kedokteran Dan Kesehatan. Edisi 5. Jakarta: Salemba Medika.

Eley, Diann S. dkk. 2013. The Relationship Between Resilience And Personality Traits In Doctors: Implications For Enchancing Well Being. Jurnal PeerJ.

Feldman, Robert S. 2012. Pengantar Psikologi. Jakarta: Salemba Humanika.

Haryuni, Sri dkk. 2013. Hubungan antara Stres Kerja dengan Kinerja Perawat di Instalasi Gawat Darurat RSUD Ngudi Waluyo Kabupaten Blitar dan RSUD Mardi Waluyo Kota Blitar. Jurnal Keperawatan, Vol. 4, No.1, 2014, ISSN 2086-3071.

Kriswandaru. 2010. Stres Kerja. /http://archive.kaskus.co.id/thread/4437750 /0/share-artikel-stress-kerja (Diakses 9 Oktober 2016).

Luthans, F. 2007. Perilaku Organisasi. Jakarta: Salemba Empat.

Mangkunegara, A. A, Anwar Parabu. 2004. Quality of life and Work in Europe. University of Gothenburg Sweden: Palgrave Macmillan.

Mathew, M.N.A. 2013. Effect of Stress on job Satisfaction among Nurses in Central Kerala. Journal of Business And Management,7(2), 47.

Muthukrishnan, N, et al. 2011. Factors Driving Occupational Stress Of Employees mampu meningkatkan kenyamanan perawat dalam bekerja sehingga dapat meningkatkan kepuasan kerja. Perawat yang bahagia dan nyaman dalam bekerja dan mempunyai resiliensi of efficacy yang tinggi akan mampu meningkatkan mutu layanan keperawatan kepada masyarakat sehingga kepuasan pasien meningkat.

Working In Hospital In Dehradun. International Journal of Research in IT \& Management.61:77.

Nuari, Nian Afrian. 2015. Model Peningkatan Resiliensi Anak Usia Sekolah Pasca Letusan Gunung Kelud Kediri Berbasis Disaster Nursing Competency. Jurnal Sainmed, Kopertis 7, Vol.7, No.2. http://dev2.kopertis7.go.id/jurnal_lengkapSainmed-7-2-01\%2012\%202015.

Nuari, Nian Afrian. 2016. Quality of Work Life and Job Satisfaction of Nurses in Amelia Hospital Pare.Jurnal Ners dan Kebidanan, Vol. 3, $\quad$ No.1, 2016. http://jnkjournal.com/index.php/jnk/article/ view/008

Papalia, Diane E dkk. 2009. Human Development. Jakarta: Salemba Medika.

Rees dkk. 2015. Understanding Individual Resilience In The Workplace: The International Collaboration Of Workforce Resilience Model. Jurnal Frontiers in Psychology.

Yana, Dewi. 2015. Stres Kerja pada Perawat Instalasi Gawat Darurat di RSUD Pasar Rebo Tahun 2014. Jurnal Administrasi Kebijakan Kesehatan, Vol. 1, No.2.

Yuniar, IGAY, Nurtjahjanti, H, Rusmawati, D. 2012. Hubungan antara Kepuasan Kerja dan Resiliensi dengan Organizational Citizenship Behavior (OCB) pada Karyawan Kantor Pusat PT. BPD Bali. Jurnal Empati. Vol.1. UNDIP. http: //ejournal3.undip.ac.id/index.php/empati/in dex. 